Chirurgia (2018) 113: 712-718

No. 5, September - October

Copyright $\odot$ Celsius

http://dx.doi.org/10.21614/chirurgia.113.5.712

\title{
Breast Metastasis as a Presentation of Malignant Melanoma
}

\section{Amira Asaad', Abdalla Saad Abdalla Al-Zawi', Philip Idaewor', Buddhika Jayasooryia', Victoria Yates' Soad Eldruki ${ }^{2}$, Jessica English ${ }^{1}$}

${ }^{1}$ Basildon \& Thurrock University Hospital, Essex, England

${ }^{2}$ Department of Pathomorphology, Benghazi Medical Centre, Libya

Corresponding author:

Abdalla Saad Abdalla Al-Zawi M.B.B.Ch, SD in Surgery, PhD, FRCS

Consultant Surgeon, Basildon University Hospital-England

E-mail: abdalasaad@gmail.com

\section{Rezumat \\ Metastaze mamare din melanom malign}

Majoritatea leziunilor mamare maligne sunt tumori primare, $\mathrm{cu}$ originea în țesutul mamar. Cancerele mamare primare metastazează de regulă în ganglionii limfatici, plămâni, oase şi creier. Metastazele în sân din cancere ale altor organe sunt foarte rare, dar au fost întâlnite la pacienți cu melanom malign, tumori carcinoide sau carcinom pulmonar. Prezentul articol raportează un caz de metastază mamară din melanom malign.

Cuvinte cheie: cancer mamar, melanom malign, antigenul de melanom

\section{Abstract}

The majority of malignant breast lesions are primary tumors originated from breast tissue. These primary breast cancers usually metastasize to lymph nodes, lungs, bones and brain. Metastases from cancers of other organs to the breast are very rare, but have been encountered in patients with malignant melanoma, carcinoid tumors or lung carcinoma. The present paper reports a case of mammary metastasis from malignant melanoma.

Key words: breast cancer, malignant melanoma, melanoma antigen 


\section{Introduction}

The differential diagnosis of malignant lesions in the breast skin or parenchyma includes primary or metastatic neoplasm. Although the presence of metastatic cancer in the breast from other remote primary cancers is a rare phenomenon, primary breast cancer remains one of the leading causes of death in women. Trevithick reported the first case of extramammary breast metastasis in 1903 (1). The most commonly reported primary site for breast metastase is the contralateral breast (2). Other cancers known to metastasise to breast may include malignant melanoma (MM), renal adenocarcinoma, haematological ma-lignancy, melanoma and prostate. MM is a very aggressive neoplasm, with unpredictable evolution and a low survival rate. In fact it is ac-countable for $75 \%$ of skin cancer deaths (3). Metastatic disease is no-ticed in 20\% of MM cases (4), it may disseminate via haematogenous or lymphatic streams.

\section{Case Report}

A 57-year-old female patient was seen in breast clinic for triple assessment. She presented with a recent history of lump in her left breast, however also she reported a history of significant back pain for few months. She had no other significant previous medical history.

Examination revealed she had a $3 \mathrm{~cm}$ suspicious left breast lump in the upper outer quadrant. The subsequent mammogram revealed a $25 \mathrm{~mm}$ lobulated mass lesion in this region of the left breast that was surrounded by numerous other smaller lesions (Figs. 1, 2). Breast ultrasound revealed further smaller lesions in the lower outer quadrant of the left breast (Fig. 3). These were highly suspicious of multi-centric malignancy. The breast imagingguided biopsy showed cores of breast tissue infiltrated by sheets of poorly differentiated malignant neoplasm. The tumour cells were composed of moderately abundant pale eosinophilic cytoplasm containing large pleomorphic nuclei, some intra nuclear vacuoles and others with prominent nucleoli (Figs. 4, 5).

Staining for MeIA "Melanocyte specific cytoplasmic protein called Melanoma Antigen" (Figs. 6, 7) and E-Cadherin "Epithelial calciumdependent cell adhesion protein" was positive.

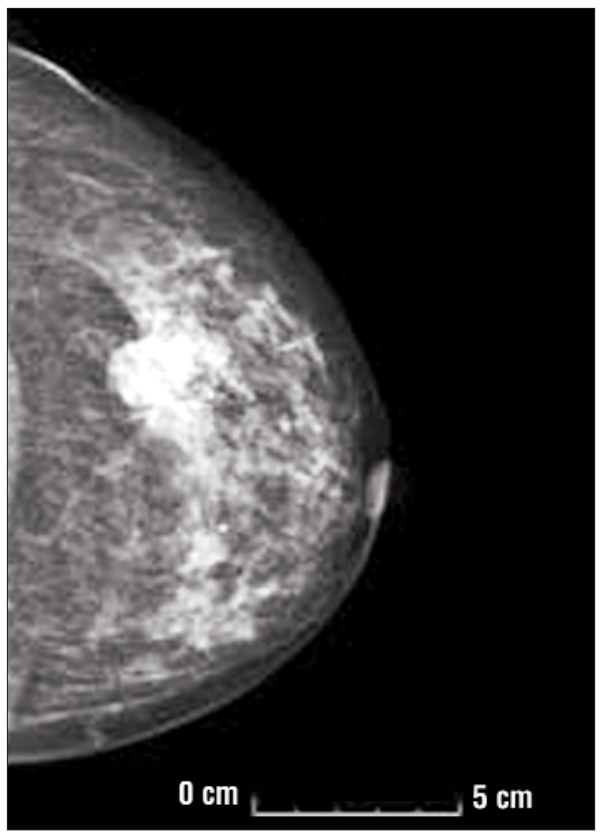

Figure 1. Left mammogram CC view- $25 \mathrm{~mm}$ lobulated mass lesion surrounded by numerous other smaller lesions in the left breast upper outer quadrant

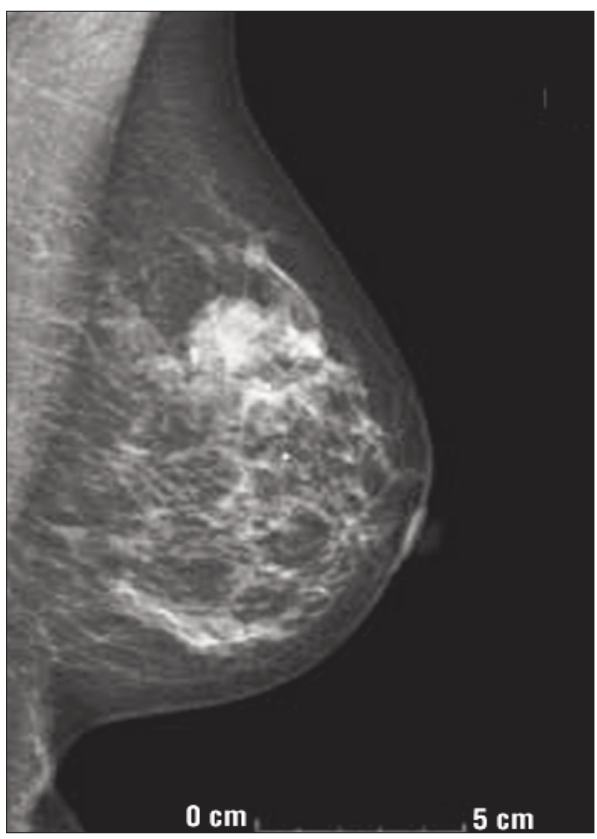

Figure 2. Left mammogram MLO view-25 $\mathrm{mm}$ lobulated mass lesion surrounded by numerous other smaller lesions in the left breast upper outer quadrant 


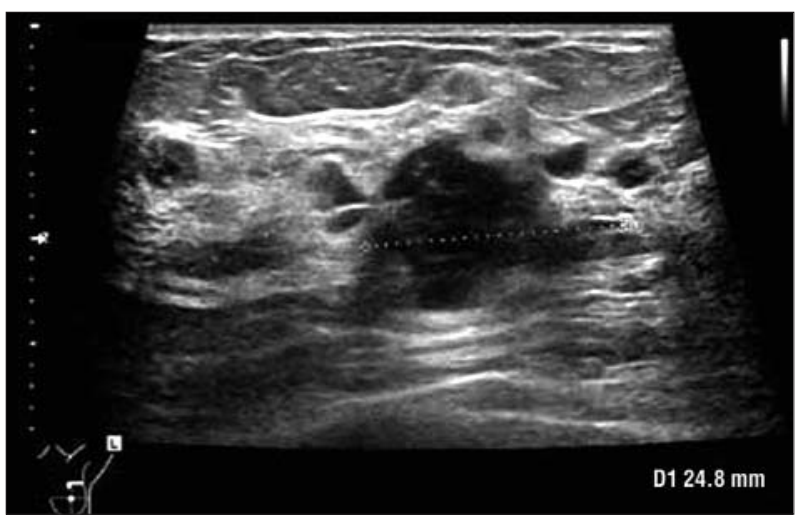

Figure 3. Left breast ultrasound showing $25 \mathrm{~mm}$ lobulated mass lesion surrounded by numerous other smaller lesions in the left breast upper outer quadrant

Staining for ER "Oestrogen Receptor" (Fig. 8), PR "Progesterone Receptors" (Fig. 9), Cytokeratin AE1/AE3 "Keratin cocktail that detects CK1 -8, 10, $14-16$ and 19 "(Fig. 10) and CAM 5.2 "Commonly used antibody to cytokeratins 8 and to a lesser extent CK7 " (Fig. 11) was negative. The Ki-67 proliferative index was high (Fig. 12). The immune-profile was consistent with metastatic melanoma. Staging CT scan showed multiple liver and bone metastases in addition to multiple small metastatic lung deposits (Figs. 13, 14, 15). An MRI spine also showed multiple deposits in the spine, in keeping with metastatic disease. Furthermore there was a biconcave pathological fracture of L2. The patient has been referred for palliative oncology management. CT head wasn't requested in this case as the patient has had no neurological

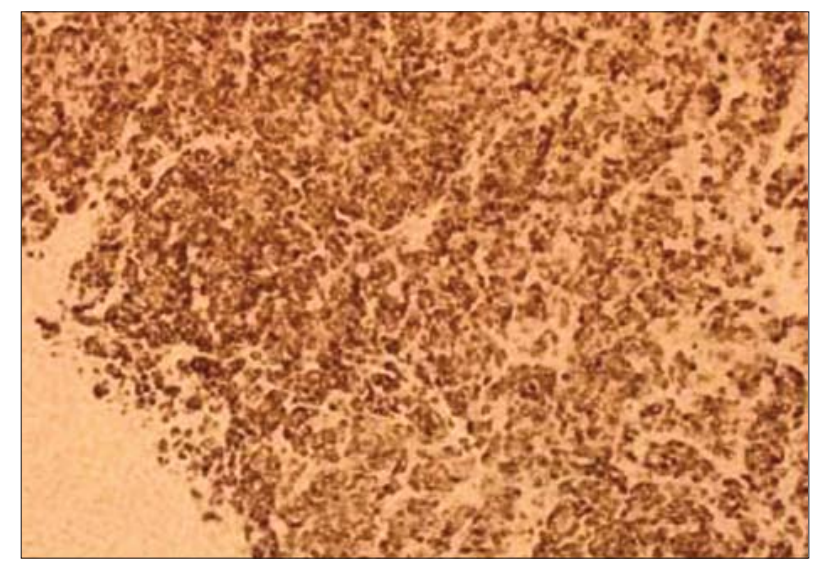

Figure 6. Tumour cells are MelA positive. X10

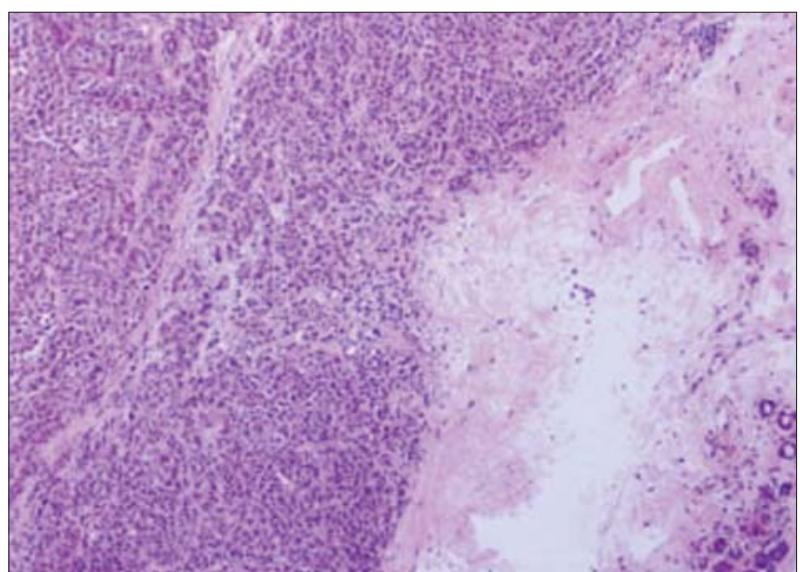

Figure 4. H\&E. Cores of breast tissue infiltrated by sheets of poorly differentiated malignant neoplasm. The tumour cells are composed of moderately abundant pale eosinophilic cytoplasm containing large pleomorphic nuclei, some intra nuclear vacuoles and others with prominent nucleoli. X10

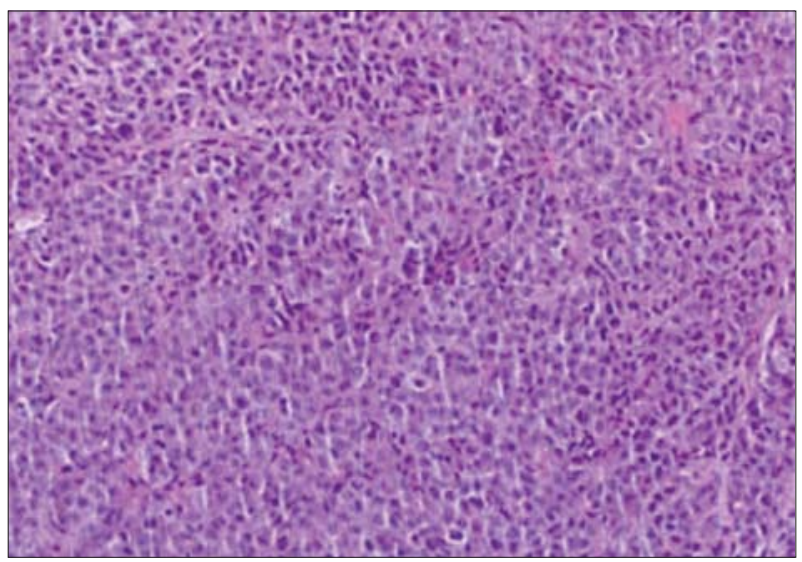

Figure 5. H\&E. Cores of breast tissue infiltrated by sheets of poorly differentiated malignant neoplasm. X20

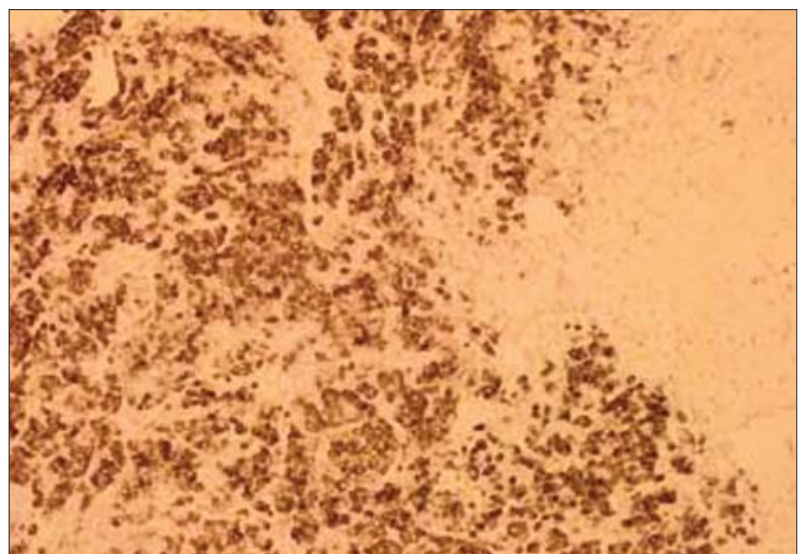

Figure 7. Tumour cells are MelA positive. X20 


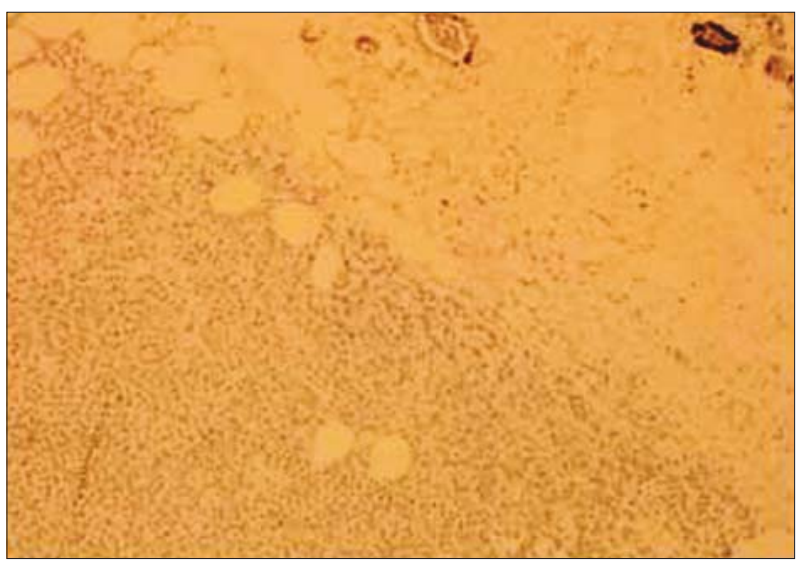

Figure 8. Tumour cells are ER negative

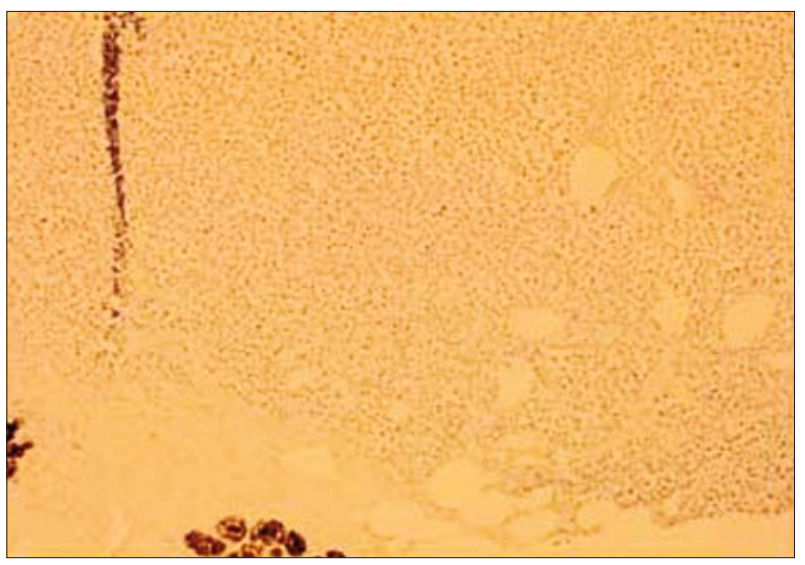

Figure 10. The tumour is AE1/AE3 negative 10x

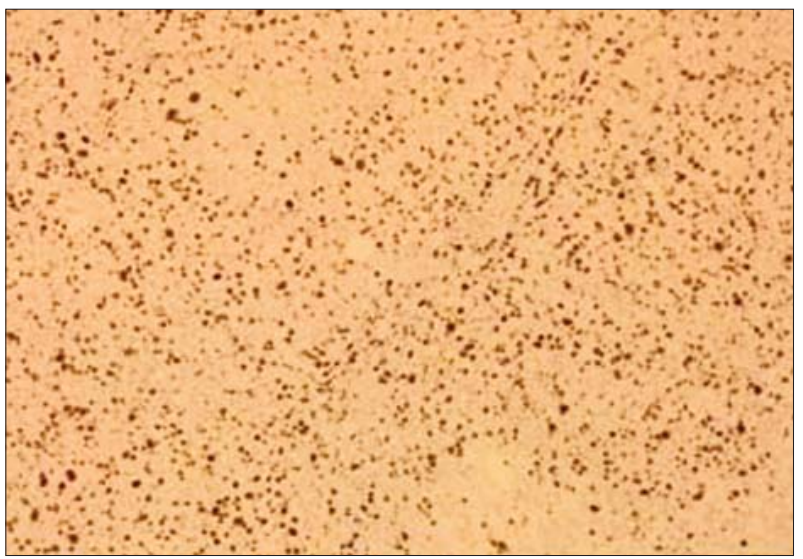

Figure 12. The Ki-67 proliferative index was high

symptoms initially then her general condition deteriorated rapidly.

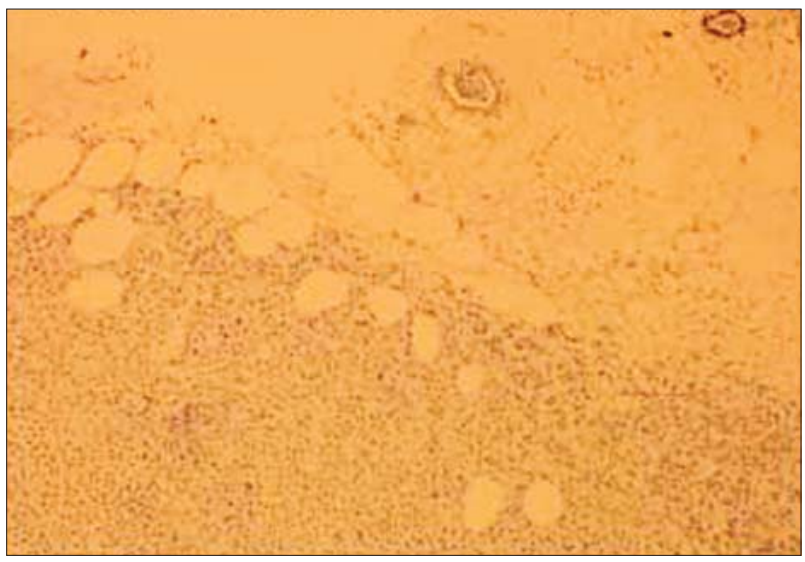

Figure 9. Tumour cells are PR negative

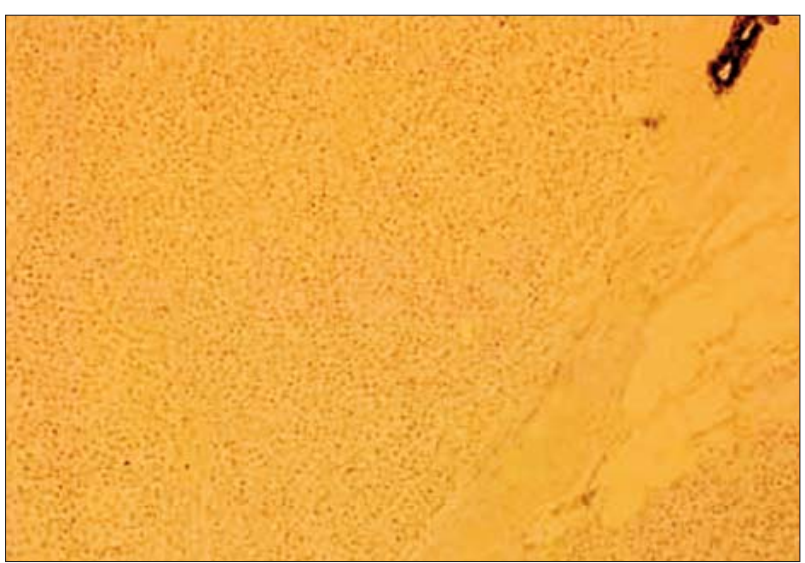

Figure 11. The tumour is CAM 5.2 negative

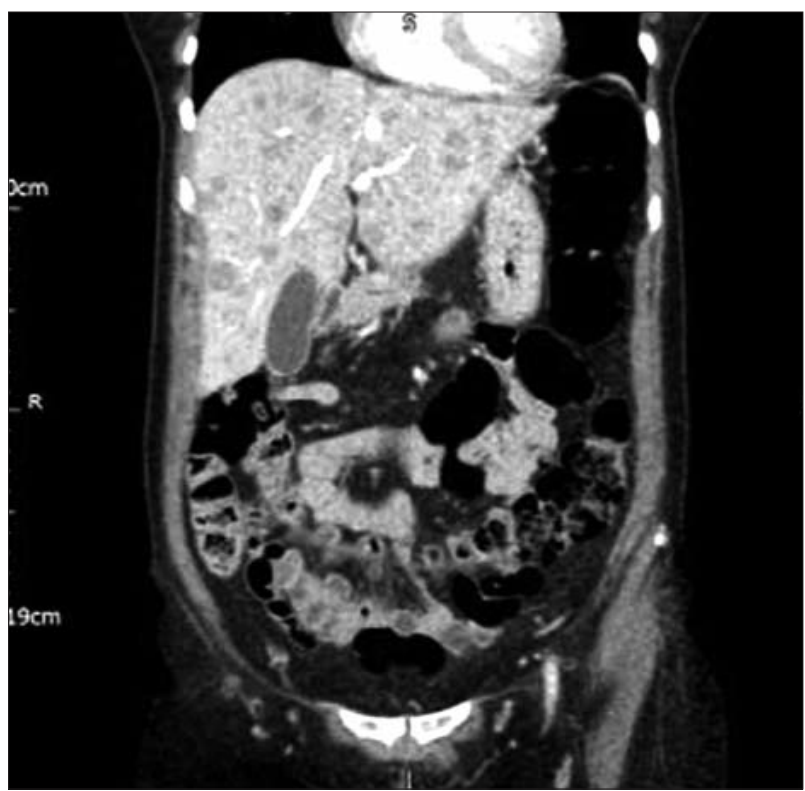

Figure 13. Coronal view of CT abdomen \& pelvis: multiple deposits in the liver 


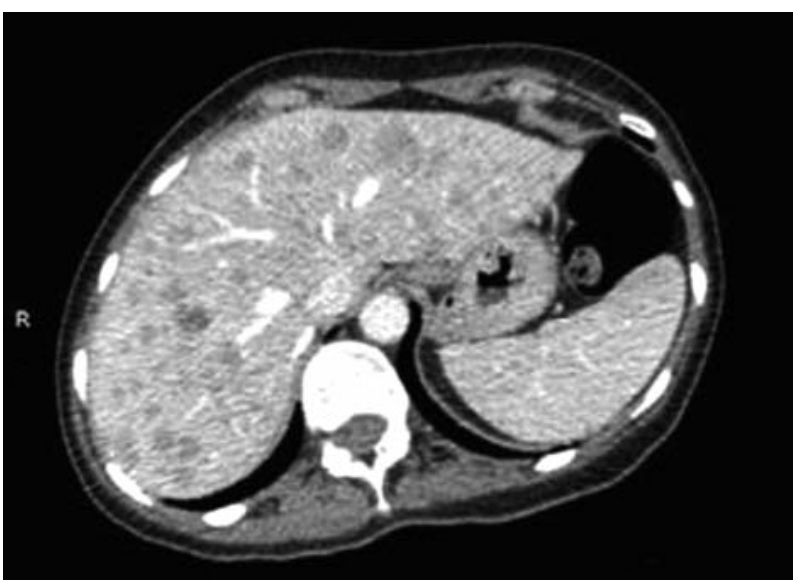

Figure 14. Axial view of CT abdomen showing multiple deposits in the liver

\section{Discussion}

Malignant melanoma (MM) is the second most aggressive skin cancer af-ter Merkel cell carcinoma (5) and is known to have the most rapidly ris-ing incidence. Even though it accounts for just $5 \%$ of all malignant skin tumours, $75 \%$ of skin cancer deaths are related to MM (3). The incidence is increasing about $5 \%$ per year worldwide (6) and metastatic disease occurs in $20 \%$ of patients with MM (4). The reported sites for metastasis are lymph nodes (7), brain (8), breast (9), lung (10), pleura $(6,11)$, bone $(12)$ and myocardium (13). Metastatic disease is usually associated with poor prognosis.

MM is originated from melanoblasts or melanocytes. In addition to the skin, MM is also found in the eyes, ears, mouth, gastrointestinal tract, genital mucosa, and leptomeninges (14). Histologically melanoma in the breast could arise primarily in the breast skin or parenchyma, as metastasis in the breast parenchyma, or in-transit metastases to breast tissue or breast skin (15). Primary malignant melanomas observed on the breast skin account for $5 \%$ of all malignant melanomas $(16,17)$.

The breast itself is recognised as an unusual site to harbour a metasta-tic disease from other remote tumours. In fact breast metastasis from extra-mammary sites presents only in

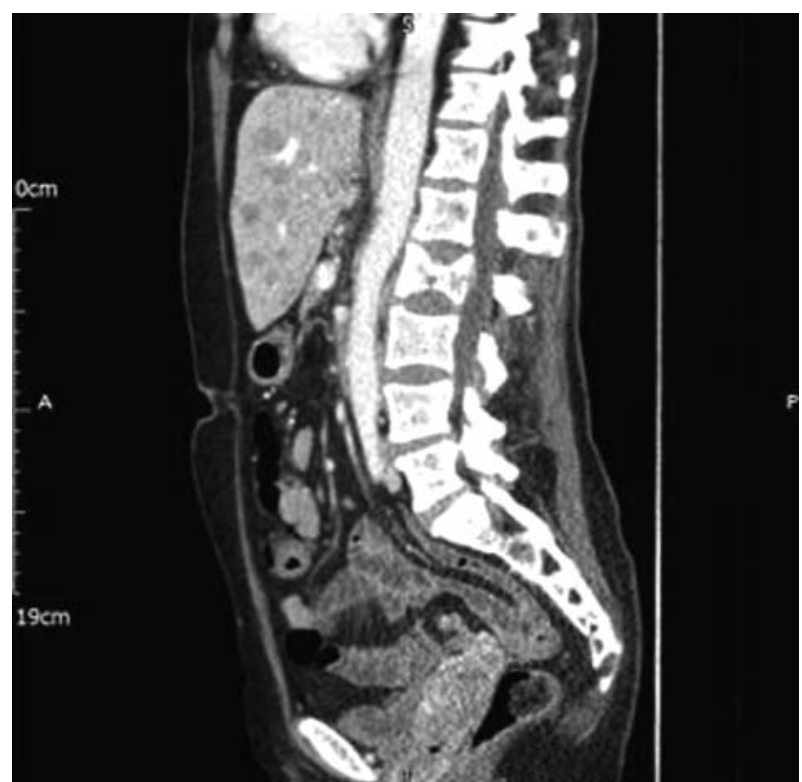

Figure 15. Sagittal view of CT abdomen \& pelvis: Multiple deposits in the liver and spine with biconcave pathological fracture of $L 2$

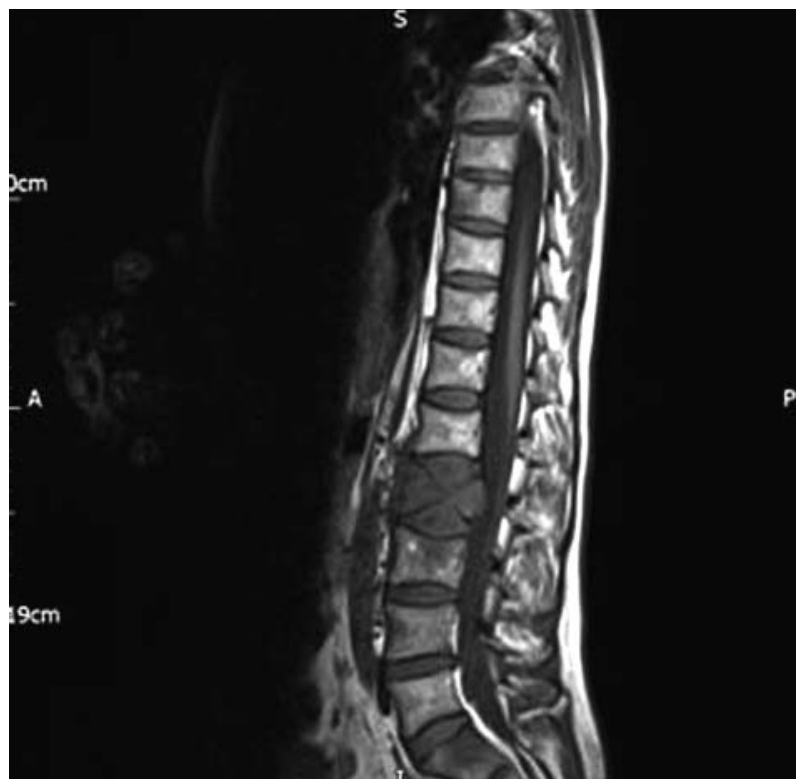

Figure 16. MRI spine (Sagittal view) with biconcave pathological fracture of $L 2$

$1.3 \%-2.7 \%$ of all malignant mammary tumours (18). Hence the contralateral breast is reported to be the most common source of primary cancer to metastasise to the breast. The other extra-mammary cancers known to metastasise to breast may include haematological malignancy malignant melanoma (MM), appendicular carcinoid, malignant 
mesotheliomas, epidermoid cervical carcinoma, renal, lung (19), gastric, pancreatic, rectal (20) ovarian (21), tongue, thyroid (22) and prostate carcinomas. Contrast-ingly, rhabdomyosarcoma is the most common cancer to metastasise to the breast in paediatric age group (23).

Breast metastases from MM often affect pre-menopausal females (22,24), a considerably younger cohort than patients affected by other tu-mours with breast metastatic involvement. The upper outer quadrant (UOQ) of the breast is involved in about $50 \%$ of cases. This is explained by good blood supply and more dense glandular tissue $(4,10,18,25)$. The breast UOQ is also known to be a frequent site for primary breast malignancy (26), and in absence of features of remote primary cancer in case of breast metastases, this may complicate the diagnosis process.

With some patients, knowing the primary site will not change the man-agement plan, In addition to that, the patient may deteriorate very rapidly and no time for further investigations. CT head wasn't requested in this case as the patient has had no neurological symptoms initially then the general condition deteriorated rapidly. The decision was to offer her the best supportive care immediately.

The presentation of remote cancers with breast metastasis is mostly with symptoms from the primary tumour, however patients may present with breast lesions as the first symptom (20).

Metastatic MM has a very poor prognosis, with a 5-years survival rate between 5-19\%, and is dictated by the location and the number of metastases (27).

\section{Conclusion}

The presence of disseminated metastatic malignancy including breast lump, may be associated with a remote primary other than breast ori-gin.Metastases from malignant melanoma to the breast could reflect a widespread disease and a high possibility of poor outcome. prognosis is rather poor in cases with diagnosed malignant melanoma metastasis to the breast.

\section{Authors' Contributions}

Conceived, designed, analysed and collected data. Performed analysis, wrote paper.

\section{Conflict of Interest}

All author declare that they have no conflict of interest.

\section{References}

1. Trevithick E A case of chloroma with clinical history and account of post mortem appearances. Lancet.1903;2:158-160.

2 Williams SA, Ehlers RA 2nd, Hunt KK, Yi M, Kuerer HM, Singletary $\mathrm{SE}$, et al. Metastases to the breast from nonbreast solid neoplasms: presentation and determinants of survival. Cancer. 2007; 110(4):731-7.

3 Rigel DS, Russak J, Friedman R. The evolution of melanoma diagnosis: 25 years beyond the ABCDs. CA Cancer J Clin. 2010;60(5):301-16.

4 Majeski J. Bilateral breast masses as initial presentation of widely metastatic melanoma. J Surg Oncol.1999;72 (3):175-7.

5 Saad Abdalla Al-Zawi A, Prodromou A, Chicken W, Comez T, Deniz E. Merkel Cell carcinoma; Literature Review. Nowotwory Journal of Oncology. 2017;67,2:127-131.

6 Yang B, Li Q, Zhao H, Liu H, Tang T, Jiang C. Local anaesthetic thoracoscopy for the diagnosis of metastatic pleural melanoma originated from oral malignant melanoma: A case report and comments. Yang et al. World Journal of Surgical Oncology. 2015;13:326.

7 Lewis KD, Dollarhide S, Fitzpatrick JE, Gonzalez R, High WA, McCarter $M D$, et al. Metastatic malignant melanoma from an unknown primary presenting as a large axillary mass.Oncology (Williston Park). 2006; 20(7):763-70.

8. Alqahtani S, Alhefdhi AY, Almalik O, Anwar I, Mahmood R, Mahasin Z, et al. Primary oral malignant melanoma metastasis to the brain and breast: A case report and literature review. Oncol Lett. 2017;14(2): $1275-1280$.

9. Saad Abdalla Al-Zawi A, Osayi K, Eades MJ. Breast Meta-stasis from a Malignant Melanoma-A Case Report. Int J Radiol Radiat Ther. 2017; 3(3):00062.

10. Al Samaraee A, Khout $H$, Barakat $T$, Fasih T. Breast metastasis from a melanoma. Ochsner J. 2012;12(2):149-51.

11. Mytinger AK, Lim KG, Kern RM, Mullon JJ, Edell ES, Saeed AI. Pleural meta $\neg$ stases from cutaneous malignant melanoma. J Bronchology Interv Pulmonol. 2018;25(1):54-56.

12. Zekri J, Marples M, Taylor D, Kandukurti K, McParland L, Brown JE. Complications of bone meta-stases from malignant melanoma. J Bone Oncol. 2017;8:13-17.

13. Ozyuncu N, Sahin M, Altin T, Karaoguz R, Guldal M, Akyurek 0 . Cardiac metastasis of malignant melanoma: a rare cause of complete atrioventricular block. Europace. 2006;8(7):545-8.

14. McCourt C, Dolan 0, Gormley G. Malignant melanoma: a pictorial review. Ulster Med J. 2014;83(2):103

15. Kurul $\mathrm{S}$, Tas $\mathrm{F}$, Büyükbabani N, Mudun A, Baykal C, Camlica $\mathrm{H}$. Different manifestations of malignant melanoma in the breast: a report of 12 cases and a review of the literature. Jpn J Clin Oncol. $2005 ; 35(4): 202-206$.

16. Damaskos C, Dimitroulis D, Nonni A, Doula C, Koulermou G, Frangoulis $\mathrm{M}$, et al. Primary cutaneous melanoma of the breast region. Hellenic J Surg . 2016;88(4):285+287.

17. Nalbant $O A$, Vural $S$, Keles MC, Nalbant E,Kandiloglu AR. Metastatic malignant melanoma to the breast: A case report. J Breast Health. 
2011;7(1):36-39.

18. Cangiarella J, Symmans WF, Cohen JM, Goldenberg A, Shapiro RL, Waisman J. Malignant melanoma metastatic to the breast: a report of seven cases diagnosed by fine-needle aspiration cytology. Cancer. 1998;84(3):160-162.

19. Saad Abdalla Al-Zawi A, Ratajczak A, Idaewor P, Elamass M, Lazarevska A, Tan E, Barron M, Asaad A. Primary lung cancer with metastasis to the ipsilateral breast-a case report. International Journal of Research in Medical Science. 2017;6(1): 334-339.

20. Zhou Shuling, Yu Baohua, Cheng Yufan, Xu Xiaoli, Shui Ruohong, Bi Rui, et al. Metastases to the breast from nonmammary malignancies: a clinicopathologic study of 28 cases Chin J Pathol. 2014;43(04):231-235.

21. Recine MA, Deavers MT, Middleton LP, Silva EG, Malpica A. Serous carcinoma of the ovary and peritoneum with metastases to the breast and axillary lymph nodes: A potential pitfall. Am J Surg Pathol. 2004; 28(12):1646-51.

22. DeLair DF, Corben AD, Catalano JP, Vallejo CE, Brogi E, Tan LK. Non- mammry metastases to the breast and axilla: a study of 85 cases. Mod Pathol. 2013;26(3):343-9.

23. Vergier B, Trojani M, de Mascarel I, Coindre JM, Le Treut A. Metastases to the breast: differential diagnosis from primary breast carcinoma. J Surg Oncol.1991;48(2):112-6.

24. Ravdel L, Robinson WA, Lewis K, Gonzalez R. Metastatic melanoma in the breast: a report of 27 cases. J Surg Oncol. 2006;94(2):101-104.

25. Moschetta M, Telegrafo M, Lucarelli NM, Martino G, Rella L, Stabile lanora AA, et al. Metastatic breast disease from cutaneous malignant melanoma. Int J Surg Case Rep. 2014;5(1):34-6.

26. Lee AHS. Why is carcinoma of the breast more frequent in the upper outer quadrant? A case series based on needle core biopsy diagnoses. Breast. 2005;14(2):151-2.

27. Sandru A, Voinea S, Panaitescu E, Blidaru A. Survival rates of patients with metastatic malignant melanoma. J Med Life. 2014; 7(4):572-6 